\title{
The Use of Constructions in The Novel The Autumn of The Patriarch by Gabriel Garcia Marquez
}

\author{
Sri Haryanti ${ }^{1}$, Purwo Haryono ${ }^{2}$, Ana Setyandari ${ }^{3}$, Sukasih Ratna Widayanti ${ }^{4}$ \\ ${ }^{1,2,3,4}$ Universitas Widya Dharma Klaten, Indonesia
}

\section{DOI: 10.23917/humaniora.v22i2.12601}

Received: 17 November 2020. Revised: 7 April 2021. Accepted: 21 Juni 2021 Available Online: 7 Juli 2021. Published Regulary: Agustus 2021

\begin{tabular}{l}
\hline Keywords \\
\hline features, \\
long sentences, \\
clauses, \\
phrases, \\
adverbials
\end{tabular}

Corresponding Author

Sri Haryanti

Universitas Widya Dharma Klaten

Indonesia

Email:

haryanti.sirod@gmail.com

Phone: -

\section{Abstract}

The present study deals with the features of long sentences in the novel The Autumn of the Patriarch by Gabriel Garcia Marquez. This study aimed to identify the features of long sentences found in the novel and to suggest ways to comprehend the long sentences. This study is beneficial for the development of English teaching, particularly the structure course. The data were in the form of phrases, clauses, and sentences used in the novel which were collected through observation method (metode simak). Descriptive qualitative method was employed for analysing the data. The results indicated that most of the sentences were compound complex. Each clause can be identified through its subject, predicate, object, and adverb or complement. Each subordinate clause could be understood by identifying the word(s) modified and introductory word used. By identifying the main clause, sub-ordinate clause, parts of a main clause, subordinate clause, and kinds of phrases, the reader can understand the long sentences. In addition, most of the main clauses were preceded by adverbials.

\begin{tabular}{ll}
\hline Kata Kunci & Abstrak \\
\hline fitur, & Penelitian ini membahas ciri-ciri kalimat panjang dalam novel The \\
kalimat panjang, & Autumn of the Patriarch oleh Gabriel Garcia Marquez. Penelitian ini \\
frasa & bertujuan untuk mengidentifikasi ciri-ciri kalimat panjang yang \\
& ditemukan dalam novel tersebut dan berupaya untuk menunjukkan \\
& cara-cara untuk memahami kalimat panjang tersebut. Penelitian ini \\
& bermanfaat untuk pengembangan pengajaran bahasa Inggris, khu- \\
& susnya pengajaran tata bahasa. Data penelitian ini berupa frasa, \\
& klausa, dan kalimat yang digunakan dalam novel yang dikumpulkan \\
& melalui metode simak. Metode kualitatif deskriptif digunakan untuk \\
& menganalisis data. Hasil penelitian menunjukkan bahwa sebagian \\
& besar kalimat dalam novel ini merupakan kalimat kompleks. Setiap \\
& klausa dapat diidentifikasi melalui subjek, predikat, objek, dan kata \\
& keterangan atau pelengkap. Setiap klausa bawahan dapat dipahami \\
& dengan mengidentifikasi kata yang dimodifikasi dan kata penghub- \\
& ung yang digunakan. Dengan mengidentifikasi klausa utama, klausa \\
& sub-ordinat, bagian-bagian dari klausa utama, klausa subordinat, dan \\
& jenis frasa, pembaca dapat memahami kalimat yang panjang tersebut. \\
& Selain itu, sebagian besar klausa utama diawali dengan kata ket- \\
& erangan. \\
\hline
\end{tabular}




\section{INTRODUCTION}

In daily communication people use constructions which can be in the form of phrases, clauses, or sentences. Clause is subdivided into main clause and subordinate clause. The example of main clause is 'She needs to read this novel', and the example of subordinate clause is 'because this novel is the best'. Main clause can stand alone as a sentence, whereas subordinate clause cannot. A sentence can consist of one main clause or more and one subordinate clause or more. In addition, a sentence can be classified into many kinds based on some views. All of them are very much needed in delivering people's ideas, thought, suggestions, and many others in order to be received by the listeners or readers easily. When we talk about this matter, we are usually in charged with language as a means of communication which takes an important role in human life.

Grammar of language is as one of many resources for communication. It relates to how the speaker or writer wants to say or write, and how he expects others to interpret his language use and its focus (Al-Mekhlafi \& Nagaratnam, 2011). Elkilic \& Akca (2008) found students' positive attitudes of studying English grammar at a private primary EFL classroom towards studying grammar. Particularly, however, more than $50 \%$ of their subjects enjoyed grammar class and only about $10 \%$ found some difficulties in learning and remembering grammar (Al-Mekhlafi \& Nagaratnam, 2011). The studies of grammar acquisition have shown that one main precondition for learning and mastering grammatical categories is understanding the relations between language units (Saxton, 2010; Hedge, 2000; Thornbury, 1999). To do that the acquired information must be preserved and used (Skehan, 2008). The complexity of the language category and the frequency of its use determine the speed and time of acquisition (Uibu \& Liiver, 2015).

In educational aspect there is one important thing which should be considered, namely the need of instilling of moral values to the students. The teacher or lecturer can take some ways for doing this. One of them is through reading literary works. Young learners are very familiar with literary works. Their favourite one is a novel. Reading novel is very enjoyable. However, reading English novel needs an understanding of its content and meaning. To do this of course the reader should understand the sentences used. Sentences cover a group of words or a phrase. One sentence can consist one phrase or more. For this reason, the researchers were interested in analysing the long sentences used in novel The Autumn of the Patriarch by Gabriel Garcia Marquez.

Aqel says that in addition to the four skills in any language, the grammar is an elementary mainstay. EFL researchers and teachers should investigate the most appropriate method to enable students to understand the rules easily and to present accurate forms (Aqel, 2013). In the conclusion of his article he recommended that the applying of grammatical structure or the practicing of the language skills in general should be in the target language to confirm the needed forms 
that the learners must develop to achieve the best results they are looking for (Aqel, 2013).

As English has already become a global lingua-franca and the language of power in many contexts in the world, grammatical usage and accurate language use is especially necessary for EFL/ESL learners who need English for economic empowerment and upward mobility in many societies (Peirce, 1989; De Wet, 2002) in (Uysal \& Bardakci, 2014). As one element which supports the language skills, it covers how to arrange constructions such as phrases, clauses, and sentences.

Phrase is a group of words, without a finite verb), especially one that forms part of a sentence (Hornby, 2000). Phrase is a combination of two words or more, which is not predicative. For example, "the green book" is a phrase because it is not predicative. Phrase is a group of words which does not constitute the 'subject-predicate' construction.

There are kinds of phrases in English, they are noun phrases, verb phrases, adjective phrases, adverb phrases, prepositional phrases, and verbal phrases (gerund phrases, participle phrases, to-infinitive phrases). Noun phrase is a group of words in which the head word is a noun, such as "a man having two houses", "a strong and handsome boy", "the lecturer in front of the office", "the book stolen yesterday". In these examples, the words man, boy, lecturer, and book are head words in the phrases, and they are called head word or key word. Verb phrase is a combination of an auxiliary verb with the main verb which becomes a predicate, such as: "The boy is standing behind you", "The book has been read many times", "She has been waiting for you for more than three hours". Verb phrase always functions as predicate in a sentence. Verb phrase is also accompanied by modal auxiliaries such as shall, will, may, can, should, would, might, could, must. Modals can be in the form of present or past tense: will-would, may-might, can-could, shall-should. The example of the pair can be seen in the sentences: "The tramp says that he will read the diary". And "The tramp said that he would read the diary". Prepositional phrase is a group of words beginning with a preposition and ending with noun, pronoun, or gerund, as the following: "at the store", "for them", "among those books", "for studying". Noun, pronoun or gerund, here become objects of preposition; therefore, their forms are also in objects (them, him, her) etc.

Clause is a group of words that includes subject and a verb, and forms a sentence or part of a sentence (Hornby, 2000). A term used in some models of grammar to refer to a unit of grammatical organization smaller than the sentence, but larger than phrases, words or morphemes is called a clause. The traditional classification is of clausal units into main (independent or superordinate) and subordinate (or dependent) clauses, e.g. The girl arrived/after the rain started (Crystal, 2008). 
Clauses can be subdivided into two, namely main clause and subordinating clause. If the main clause can stand alone, it can be called a sentence. Sentence can consist of one main clause or more, that is when the sentences consisting of pair of subjects and predicate are joined by using coordinate(coordinating) conjunction: and, but, so, etc. Subordinate clause is a clause which cannot stand alone, it is only a part of the sentence or substitutes a part in the sentence.

There are three kinds of clauses in English, they are noun clauses, adjective clauses, and adverb clauses. Noun clause is a clause in complex sentence which is used as a noun does, as $\mathrm{S}, \mathrm{SC}, \mathrm{OV}$, OP, etc. Noun clause is subordinate clause used as noun and can function as subject, predicative nominative, direct object, indirect object, and object of preposition. Adjective clause is a clause functioning as adjective that is modifying noun or pronoun. Adverb clause is subordinate clause functioning as adverb, they modify predicates of the main clauses (Wahyuni., Fauziati., Hikmah., 2016).

According to (Hornby, 2000) sentence is a set of words expressing a statement, a question or an order, usually containing a subject and a verb. Sentences may be classified according to their purposes/types such as declarative, interrogative, imperative, or exclamatory. A declarative sentence makes a statement. An imperative gives a command or makes a request. The imperative sentence is followed by a period. Interrogative sentence asks a question.

Sentences may be classified according to their syntax: as simple, compound, complex, or compound-complex. A simple sentence is a sentence which consists of a pair of subject and predicate. A compound sentence is a sentence which consists of at least two main clauses or more. Compound sentences consist of two or more main clauses but other applications of the term exist, as in 'compound subjects/objects', etc. (where the clause element consists of more than one noun phrase or pronoun, as in the boys and the girls shouted) and 'compound prepositions' (e.g. in accordance with) (Crystal, 2008). Complex sentence is a sentence which consists of one main clause and one subordinate clause or more. Complex sentence is a term which in its most general application describes a sentence consisting of more than one clause. In a somewhat narrower sense, it refers to a sentence consisting of a main clause and at least one subordinate clause, thus contrasting with such notions as compound sentence (Crystal, 2008). Compoundcomplex sentence is a combination of compound sentence and complex sentence. In another words, it can be stated that a compound complex is a sentence which consists of at least two main clauses and one subordinate clause or more.

The sentence constructions used in the novel are very challenging for the researchers themselves and maybe for the readers as well. The researchers think that Indonesian students studying English will find difficulties in reading it because there are some sentences which are more than ten lines, even there are sentences which are written in one page or more. They think that when the students 
can understand the meanings of sentences, they will get more understanding about them.

There are some ways that can be used to comprehend grammar. 49 studies by Norris and Ortega (2000, 2001) and 11 studies by Ellis (2002) on a meta-analysis demonstrated that focus-on-form contributed to faster language acquisition, higher levels of accurate oral or written language production, and longer retention of forms when compared to pure meaning-focused implicit learning (Uysal \& Bardakci, 2014). This study found that teachers believed that grammar teaching is crucial for enabling students to use grammar structures correctly and favoured a traditional deductive approach involving direct teaching and explaining rules for grammar structures, drilling, and error correction as it is less timeconsuming and leads to accurate language use (Uysal \& Bardakci, 2014; Yamin,. Saputra., Deswila, 2021). This research is also in line with the opinion that in Europe, the Greeks were the first to write grammars. To them, grammar was a tool that could be used to study Greek literature.

A novel entitled The Autumn of the Patriarch by Gabriel Garcia Marquez was very interested to study because the use of sentence constructions in the novel is very unique; the sentences are too long to understand, especially by Indonesian students. They tend to have difficulties in understanding the meaning or the idea of the sentence. In addition, there is no study yet about the sentence constructions in this novel. Therefore, this study is significant as to improve the teaching and learning of English structure.

Based on the phenomenon above, the researchers tried to find out the features of long sentences in the novel with the hope that the result of this study can give some contributions in attempting to give insights to the students in learning English sentence constructions. The research question of this study can be formulated into the following questions: (1) What are the features of long sentences in the novel The Autumn of the Patriarch by Gabriel Garcia Marquez? and (2) How are the ways to understand the meanings or ideas of these sentences?

\section{METHOD}

This study was a document analysis. This research analysed sentences in the novel which can be categorized as document. Document analysis can be of written or text based artefacts such as textbooks, novels, journals, meeting minutes, logs, announcements, policy statements, newspapers, transcripts, birth certificates, marriage records, budgets, letters, e-mail messages, or of non-written records such as photographs, audiotapes, videotapes, computer images, websites, musical performances, televised political speeches, YouTube videos, virtual world settings (Ary, Jacobs, Sorensen, \& Razavieh, 2010). This research was a document analysis which is a structured research approach, using specified research designs and methods to make replicable and valid inferences from texts 
and similar materials (Krippendorff, 1980, 2013; Mayring, 2000; Neuendorf, 2002; Schreier, 2012).

This study applied qualitative approach. According to (Ritchie \& Lewis, 2003) that qualitative approach is used to address research questions that require explanation or understanding of social phenomena and their contexts. As an addition, (Webster, 2019) states that there are four characteristics which are identified by most as key to understanding the nature of qualitative research: process, understanding, and meaning are as the focus; the primary instrument of data collection and analysis is the researcher ; the process is inductive; and the product is richly descriptive. This study used observation method (metode simak) to collect the data. According to Simak method is the method conducted by observing attentively the use of language; it can be paralleled with observation method in social science, especially anthropology (Sudaryanto, 2001).

In this research, the data were in the form of phrases, clauses, and sentences used in novel The Autumn of the Patriarch by Gabriel Garcia Marquez that were taken purposively. In this case the researchers only took the sentences which consist of more than ten lines in the pages of the novel. In this research, the source of the data was the novel The Autumn of the Patriarch by Gabriel Garcia Marquez. To validate data, the researchers applied source triangulation. Patton (1984) in (Sutopo, 2006) stated that source triangulation has similar meaning as data triangulation. Source triangulation can be defined as a technique to collect the data from various sources. In this case, the researchers took some different sentences used in novel The Autumn of the Patriarch by Gabriel Garcia Marquez.

The data were analysed using descriptive qualitative analysis. There were three stages of data analysis of qualitative data: familiarizing and organizing, coding and reducing, interpreting and representing (Ary et al., 2010). In this research the researchers read and reread the sentences in the novel The Autumn of the Patriarch by Gabriel Garcia Marquez, classified the sentences into main clauses and subordinate clauses, gave the codes of data by mentioning their pages and lines, and interpreted the kinds of sentences, clauses, phrases, and meanings. In this research the writers classify the sentences used in the novel The Autumn of the Patriarch by Gabriel Garcia Marquez based on the number of clause or syntax which consist of simple sentence, compound sentence, complex sentence and compound-complex sentence.

\section{RESULT}

For the sake of data description, the researchers present only one representative data taken from the novel as follows. "Only when we turned him over to look at his face did we realize that it was impossible to recognize him, even though his face had not been pecked away by vultures, because none of us had ever seen him, and even though his profile was on both sides of all coins, on 
postage stamps, on condom labels, on trusses and scapulars, and even though his engraved picture with the flag across his chest and the dragon of the fatherland was displayed at all times in all places, we knew that they were copies of portraits that had already been considered unfaithful during the time of the comet, when our own parents knew who he was because they had heard tell from theirs, as they had from theirs before them, and from childhood on we grew accustomed to believe that he was alive in the house of power because someone had seen him light the Chinese lanterns at some festival, someone had told about seeing his sad eyes, his pale lips, his pensive hand waving through the liturgical decorations of the presidential coach, because one Sunday many years ago they had brought him the blind man on the street who for five cents would recite the verses of the forgotten poet Rube'n Dari'o and he had come away happy with the nice wad they had paid him for a recital that had been only for him, even though he had not seen him, of course, not because he was blind, but because no mortal had ever seen him since the days of the black vomit and yet we knew that he was there, we knew it because the world went on, life went on, the mail was delivered, the municipal band played its retreat of silly waltzes on Saturday under the dusty palm trees and the dim street lights of the main square, and other old musicians took the places of the dead musicians in the band". (p.7, lines 1338).

This sentence consists of main clauses and subordinate clauses. This long sentence is classified into compound complex sentence based on number of clause. It has six main clauses and twenty four subordinate clauses. Based on type or purpose, this sentence can be classified as declarative sentence.

This sentence contains the main clauses as follows: (1) Only did we realize, (2) we knew, (3) we grew accustomed to believe, (4) someone had told about seeing his sad eyes, his pale lips, his pensive hand waving through the liturgical decorations of the presidential coach, (5) we knew, and (6) we knew it.

The main clauses (1) and (2) are connected by comma. Main clause (1) is a sentence beginning with negative 'only' so the subject 'we' is preceded by auxiliary 'did'. Main clauses (2) and (3) are connected by coordinating conjunction 'and'. Main clause (2) has six subordinate clauses. Main clauses (3) and (4) are connected by comma. Main clause (3) has ten subordinate clauses. Main clauses (4) and (5) are connected by comma. Main clause (4) consists prepositional phrase which begins with preposition 'about' followed by gerund 'seeing' which has objects 'his sad eyes, his pale lips, his pensive hand'. 'Hand' is modified by participle phrase 'waving through the liturgical decorations of the presidential coach'. Main clauses (5) and (6) are connected by coordinating conjunction 'but'. Main clause (5) has two subordinate clauses. Main clause (6) has one subordinate clause.

By identifying the connecting words and punctuations the reader can identify the meaning of these clauses. The subordinate clauses of the sentence above are 
as follows (1) when we turned him over to look at his face, (2) that it was impossible to recognize him, (3) even though his face had not been pecked away by vultures, (4) because none of us had ever seen him, (5) even though his profile was on both sides of all coins, on postage stamps, on condom labels, on trusses and scapulars, (6) even though his engraved picture with the flag across his chest and the dragon of the fatherland was displayed at all times in all places, (7) that they were copies of portraits, (8) that had already been considered unfaithful during the time of the comet, (9) when our own parents knew, (10) who he was, (11) because they had heard tell from theirs, (12) as they had from theirs before them, and from childhood on we grew accustomed to believe, (13) that he was alive in the house of power, (14) because someone had seen him light the Chinese lanterns at some festival, (15) because one Sunday many years ago they had brought him the blind man on the street, (16) who for five cents would recite the verses of the forgotten poet Rube'n Dari'o and he had come away happy with the nice wad, (17) (that) they had paid him for a recital, (18) that had been only for him, (19) even though he had not seen him, (20) because he was blind, (21) because no mortal had ever seen him, (22) since the days of the black vomit, (23) that he was there, and (24) because the world went on, life went on, the mail was delivered, the municipal band played its retreat of silly waltzes on Saturday under the dusty palm trees and the dim street lights of the main square, and other old musicians took the places of the dead musicians in the band.

Subordinate clauses (1) to (5) add the meaning to the main clause 'Only did we realize'. Subordinate clause (1) preceding main clause is called adverb clause with introductory word 'when'. Sub-clause (2) is that/noun clause functioning as object of verb 'realize'. Sub-clauses (3), (4), (5), (6) are called adverb clause which all modify verb 'realize'. Sub-clause (7) is given the name with that clause/noun clause as direct object of verb 'knew'. Sub-clause (8) is called an adjective clause which modifies the word 'portrait'. 'when our own parents knew' in (9) is called adverb clause, and it has subject 'our own parents', predicate 'knew', and object in the form of noun clause 'who he was' in (10). Subclauses (11), (12), (14) and (15) are called adverb clauses. Whereas, sub-clause (13) is identified as noun clause functioning as direct object of verb 'believe'. Sub-clause (16) is called an adjective clause which modifies noun phrase 'the blind man on the street'. Sub-clause (17) is called an adjective clause which modifies noun phrase 'the nice wad'. Sub-clause (18) is called an adjective clause which modifies 'a recital'. Sub-clauses (19), (20), (21) and (22) are called adverb clauses. 'That he was there' in (23) is called noun clause which functions as object of verb 'knew'. Adverb clause in (24) consists of six clauses with pairs of subject and predicate: a) the world + went on, b) life + went on, c) the mail + was delivered, d) the municipal band + played ..., e) the other old musicians + took the places. 
Because the subordinate clauses above are very complicated, to understand the meanings the readers should pay much attention to the introductory words giving the signs that they cover subject and predicate. Actually not many words are used, however, the words that introduce sub-clauses such as "that, who, when, where, because, even though, as" that make the readers have difficulty to understand the meaning. Therefore, the meanings of subordinate clauses above can be understood easily because they are attached immediately before or after the main clauses.

\section{DISCUSSION}

On the basis of the data description, the researchers found various sentence constructions both in the forms of phrases and clauses used in the novel The Autumn of the Patriarch written by Gabriel Garcia Marquez. All data (1) - (8) consist main clauses and subordinate clauses. They can be presented in the following table.

Table 1. Number of lines, main clauses, subordinate clauses

\begin{tabular}{cccc}
\hline Number of Data & Number of Lines & Number of Main Caluse & Number of Sub-Clause \\
\hline$(1)$ & 25 & 5 & 7 \\
$(2)$ & 13 & 5 & 4 \\
$(3)$ & 22 & 11 & 9 \\
$(4)$ & 26 & 6 & 24 \\
$(5)$ & 37 & 13 & 25 \\
$(6)$ & 53 & 21 & 17 \\
$(7)$ & 62 & 32 & 32 \\
$(8)$ & 88 & 31 & 53 \\
\hline
\end{tabular}

There are subordinate clauses which consists of noun clauses, adjective clauses and adverb clauses. Each clause begins with introductory words such as "who, whose, which, as, etc. it is in line with what (Frank, 1972) states that in a dependent clause, the full predication is altered in such a way that the clause must be attached to another clause, an independent clause. The alteration may be an added introductory word (I'll go straight home after I finish my work) or a change in the form of the subject or object (They want to hire a woman who can cook French food). There are three types of dependent clauses, named according to their function in the sentence: adverbial clause, adjective clause, noun clause. The variation and number of them is as follows.

Table 2. Kinds of Clause and Introductory Words

\begin{tabular}{ccc}
\hline Noun Clauses & Adjective Clauses & Adverb Clauses \\
\hline Who $=1$ & Who $=28$ & As $=9$ \\
Which $=1$ & Which $=11$ & When $=11$ \\
That $=16$ & That $=31$ & Even Though $=4$ \\
How $=3$ & Where $=9$ & Because $=16$ \\
Where $=1$ & Whose $=1$ & Since $=3$ \\
Whether $=1$ & & If $=1$ \\
\hline
\end{tabular}




\begin{tabular}{|c|c|c|}
\hline Noun Clauses & Adjective Clauses & Adverb Clauses \\
\hline \multirow[t]{6}{*}{ What $=6$} & & As If $=2$ \\
\hline & & Whethere $=1$ \\
\hline & & Until $=5$ \\
\hline & & While $=3$ \\
\hline & & As Long As $=1$ \\
\hline & & That $=3$ \\
\hline$\sum=29$ & $\sum=80$ & $\sum=59$ \\
\hline
\end{tabular}

Most of the sentences analyzed contain main or independent clause and subordinate or dependent clause. According to (Lock, 1996) there are two kinds of structural relationship between clauses - linking and binding. In linking, the clauses are in an equal relationship. They must all be independent clauses or all dependent clauses. The clauses are either simply juxtaposed (in writing often with a comma, colon, semicolon, or dash between them) or they are joined by a subordinating conjunction (and, but, or, etc.). It can be seen in "the bells of the cathedral stopped tolling their knell and those of all the churches announced a Wednesday of jubilation, Easter rockets exploded" and "because I'm not going to have any military men or officers around, God damn it, all they're good for is to waste more milk and when there's trouble, as we've seen, they spit on the hand that feeds them".

In binding, the clauses are in a relationship of inequality. There are a number of ways in which a clause may be marked as a dependent clause: 1) by a binding conjunction such as although, if, because, etc., 2) by wh- words such as who, which, when, etc. (Lock, 1996). They can be found in 'tomorrow we'll have to see what good has come out of this mother fucking mess and what hasn't and if we don't have anything to sit on".

In most of the clauses analyzed in the previous part, noun phrases and prepositional phrases can be found. Roughly speaking, the class of noun phrases consists of those sequences that can serve as subjects of sentences and also can fulfill some other functions (Baker, 1995). As stated by (Lock, 1996) prepositional phrases which were treated as adjuncts representing circumstances are called circumstantial adjuncts. They can be seen in the clauses "who tried to escape through the main door", "while he remained lying face down on the floor two feet away from General Rodrigo de Aguilar tolerating the hail of glass and plaster". Whereas, according to (Baker, 1995) motion phrases typically indicate some kind of movement in a certain direction or toward a certain location. The examples are: (1) The tomato fell into the soup, (2) The chairman walked back up here onto the stage; (3) The lion moved toward the hyena, (4) Jones took the lawnmower around the house. Motion phrases are often quite similar in form (or even identical) to locative phrases, so that a sequence of such words which is interpreted frequently depends on the context in which it is found. 
Most of the sentences used in the novel are long. (Bailey, 2006) states that long sentences are more interesting but can be difficult to construct and read. Main clause and subordinate clause are related by introductory word or relative pronoun. (Bailey, 2006) states that relative pronouns (who/ whose/ where/ which/ that) introduce a relative clause.

There are two kinds of interpretation. In narrow meaning, interpretation is enterprise to make clear the language meaning by analysis, paraphrase and comment. Usually interpretation is focused on darkness, ambiguity, and allegory. In broad meaning, interpretation is making clear the meaning of literature work by that language, including explication or explanation of aspects such as kind of work, elements, structure, theme, or its effect. According to (Leech, 1983), heuristic strategy tries to identify pragmatic force of an utterance by formulating hypotheses and then testing based on available data. Based on the theories above in understanding the meaning of sentences used in the novel, the researchers give the ways or tips how to interpret the meaning of sentence which consists of main/independent clause and subordinate/dependent clauses. The meanings of subordinate clauses found in each sentence can be known easily because they are attached immediately before or after the main clauses. Moreover, they are signed by introductory words that had been used in the previous data such as "that, what, who, which, where, when, as, because, until, since, if, whether". Those which are introduced by 'how' mean the way ,'who' mean the person doing action, 'that' can mean the person doing action or thing causing situation/condition, 'when/as/until' mean the time, 'as/because' mean the reason, 'as if' mean the condition.

Knowing the main clause, sub-ordinate clause, parts of a main clause and subordinate clause, and kinds of phrases, the reader can know the meaning of the sentence. Besides the reader of course should know the meaning of each word. When the word is not known because it is rarely used in everyday usage, the reader can see his dictionary.

\section{CONCLUSION}

The sentence constructions used in the novel The Autumn of Patriarch by Gabriel Garcia Marques are very complicated and various. Most of the sentences are composed more than ten lines. Each sentence consists of more than five main clauses and subordinate clauses. Therefore, most of the sentences are classified into compound-complex sentence based on number of clause. The subjects and objects of the main clauses and subordinate clauses are in the form of both nouns and noun phrases. The verbs or predicates of the main clauses and subordinate clauses are in the form of both verbs and verb phrases. The adverbs and complements of the main clauses and subordinate clauses are in the form of prepositional phrases and to-infinitive phrases. All of three subordinate/dependent 
clauses, namely noun clauses, adjective clauses, and adverb clauses are used in the sentence.

The meanings of the sentences can be understood only when the reader identifies each function of each construction. All subjects in the main clauses and subordinate clauses are in the form of noun phrases with predicates of verb phrases, objects of noun phrases and adverb phrases as modifiers and complements. Subjects perform the action, predicates do action, objects receive action. Complements and adverbs give a complete information of the clause or sentence. The dictionary is of course needed to know the exact meaning of a word.

As stated by (DeCapua, 2017) that languages differ in the types and applications of rules, therefore, ESL/ EFL learners need to learn the new patterns of the language they are studying. The learners should be aware of different patterns of languages and able to subconsciously produce the new language without explicit reference to rules. The language users not applying the rules which are inferior or sloppy forms of the language. The correct rules must often be explicitly learned and practiced, and may at times be contrary to what even highly educated native speakers use in formal language contexts.

\section{REFERENCES}

Al-Mekhlafi, A. M., \& Nagaratnam, R. P. (2011). Difficulties in teaching and learning grammar in an EFL context. International Journal of Instruction, 4(2), 69-92.

Aqel, I. M. (2013). The effect of using grammar-translation method on acquiring English as a foreign language. International Journal of Asian Social Science, 3(12), 2469-2476.

Ary, D., Jacobs, L. C., Sorensen, C., \& Razavieh, A. (2010). Introduction to research in education ( $8^{\text {th }}$ ed.). United States of America: Wadsworth, Cengage Learning.

Bailey, S. (2006). Academic writing, a handbook for international students (2nd Ed.). Great Britain: MPG Books Ltd, Bodmin.

Baker, C. L. (1995). English syntax (2nd Ed.). Cambridge: The MIT Press.

Crystal, D. (2008). A dictionary of linguistics and phonetics. United States of America: Blackwell.

DeCapua, A. (2017). Grammar for teachers, a guide to American English for native and non-native speakers (2nd Ed.). Switzerland: Springer International Publishing.

Frank, M. (1972). Modern English, a reference guide. New Jersey: Prentice Hall, Inc.

Hornby, A. S. (2000). Oxford advanced learner's dictionary (6th ed.). Oxford: Oxford University Press.

Leech, G. (1983). Principles of pragmatics. London: Longman Group Limited.

Lock, G. (1996). Functional English grammar, an introduction for second language teachers. Cambridge: Cambridge University Press. 
Ritchie, J., \& Lewis, J. (2003). Qualitative research practice: a guide for social science students and researchers. London: SAGES Publications Ltd.

Sudaryanto. (2001). Metode dan aneka teknik analisis bahasa: pengantar penelitian wahana kebudayaan secara linguistis. Yogyakarta: Duta Wacana University Press.

Sutopo. (2006). Metode penelitian kualitatif. Surakarta: Sebelas Maret University Press.

Uibu, K., \& Liiver, M. (2015). Students' grammar mistakes and effective teaching strategies. International Journal of Teaching and Education, III(1), 70-87.

Uysal, H. H., \& Bardakci, M. (2014). Teacher beliefs and practices of grammar teaching: focusing on meaning, form, or forms? South African Journal of Education, 34(1), 1-16.

Wahyuni, N. T., Fauziati, E., \& Hikmah, M. (2016). The effectiveness of using phonics instruction and storybooks in English reading classes to improve student participation. Jurnal Penelitian Humaniora, 17(1), 49-64.

Webster, M. (2019). Definition of character.

Yamin, M., Saputra, A., \& Deswila, N. (2021). Enhancing Critical Thinking in Analyzing Short Story "The Lazy Jack" Viewed from Identity Theory. Indonesian Journal on Learning and Advanced Education (IJOLAE), 3(1), 30-39. 